\title{
The Freud-1/CC2D1A Family: Multifunctional Regulators Implicated in Mental Retardation
}

\author{
Anne M. Millar, Tatiana Souslova and Paul R. Albert \\ Ottawa Hospital Research Institute (Neuroscience), \\ Department of Cellular and Molecular Medicine, University of Ottawa, Ontario, \\ Canada
}

\section{Introduction}

\subsection{Mental retardation}

Mental retardation is classified by the DSM-IV-TR as a developmental disorder, with diagnosis contingent upon the presence of three cardinal features: below average cognitive function (IQ $\leq 70)$; significant deficits in multiple adaptive skill domains, and; onset prior to eighteen years of age (American Psychiatric Association. \& American Psychiatric Association. Task Force on DSM-IV., 2000). The prevalence of MR, while difficult to ascertain, is often cited as affecting 1-3\% of the population (Chechlacz \& Gleeson, 2003; Leonard \& Wen, 2002; McDermott, et al., 2007). Complicating an understanding of the disorder is the fact that a spectrum of phenotypes are subsumed under the term mental retardation, which can manifest as a variety of syndromes with differing degrees of impairment. Genetic and chromosomal abnormalities as well as environmental factors (infections, malnutrition, trauma, toxins, etc.) have been implicated as playing a causal role in the development of MR, however idiopathic MR is the single most common origin, accounting for $30-50 \%$ of cases (McDermott, et al., 2007). The diversity of MR in terms of presentation and etiology reflects the heterogeneity of the disorder and has confounded a complete understanding of its pathophysiology. It is clear that MR causes substantial impairment, thus the need exists to clarify and characterize factors contributing to the disrupted developmental processes that result in MR. In an attempt to understand the underlying developmental mechanisms affected in MR, this chapter will examine one variant of MR, non-syndromic mental retardation (NSMR). In particular, the potential contribution of one gene/protein product, CC2D1A, will be explored in the development of NSMR.

\subsection{Non-syndromic mental retardation}

NSMR is the term applied to those developmental disorders meeting the diagnostic criteria for MR in the absence of any other abnormalities or deficits and accounts for 30$40 \%$ of MR diagnoses. Of those cases with a known genetic cause, both X-linked and autosomal inheritance patterns have been observed in NSMR (Basel-Vanagaite, et al., 
2003). However, the limited study of NSMR has resulted in a mere eight genes being identified in the etiology of autosomal recessive NSMR. These include PRSS12, encoding a neuronal serine protease (Molinari, et al., 2002), CRBN, encoding a ATP-dependent Lon protease (Higgins, et al., 2004), GRIK2, encoding the ionotropic glutamate receptor 6 (Motazacker, et al., 2007), TECR, a synaptic glycoprotein (Caliskan, et al., 2011), TUSC3, an oligosaccharyltransferase required for N-glycosylation (Garshasbi, et al., 2008; Khan, et al., 2011; Molinari, et al., 2008), TRAPPC9, a neuronal protein trafficking complex involved in NF-KB activation (Mir, et al., 2009; Mochida, et al., 2009), SOBP, a nuclear zinc finger protein (Birk, et al., 2010) and CC2D1A (Basel-Vanagaite, et al., 2006). The latter, CC2D1A, located in chromosomal region 19p13.12-13.2, has been identified as a locus for autosomal recessive NSMR (Basel-Vanagaite, et al., 2003). Within this region, a mutation in the coiled coil and $\mathrm{C} 2$ domain containing $1 \mathrm{~A}$ (CC2D1A) gene generates a truncated protein product, with affected individuals being homozygous for this mutant protein (Basel-Vanagaite, et al., 2003; Basel-Vanagaite, et al., 2006). The mutation related to NSMR is a $3.6 \mathrm{~kb}$ deletion in the $\sim 900 \mathrm{~kb}$ gene region which produces a frame shift, creating a premature stop codon and resulting in a truncated protein which lacks a number of potentially functional domains, including a single DM14 domain, a HLH domain and a C2 domain $(\mathrm{Ou}$, et al., 2003). It is feasible that the remaining domains in this truncation mutant, the three DM14 domains, may allow the protein to retain some function. In support of this, a recent report found that in mice, CC2D1A knockout is lethal (shortly after birth) due to respiratory failure, however no gross anatomical changes were evident (Zhao, et al., 2011). This study also found abnormal EPSC and IPSC amplitudes in cortical neurons harvested from the knockout animals, implicating CC2D1A in synapse maturation. Overexpression of CC2D1A following embryonic development partially rescued this phenotype. These data suggest that either the truncation mutant present in NSMR retains some function to support non-lethality in humans or that the mouse is more sensitive to the loss of CC2D1A. Given the $82 \%$ amino acid sequence identity between mouse and human CC2D1A, the former is perhaps more plausible, however, this has yet to be explored fully.

\subsection{CC2D1A}

Human CC2D1A belongs to a gene family consisting of two homologous genes: CC2D1A and CC2D1B, which share critical domains (indicated below) with $40.8 \%$ amino acid identity (Hadjighasem et al. 2009) and are conserved across the animal kingdom. Another protein, CC2D2A, with domain (but not sequence) similarity has also been identified and is associated with mental retardation (Noor, et al., 2008). CC2D1A has also been termed Freud1, Aki1 and TAPE in the literature depending on its function. Sequence alignments indicate substantial sequence identity with mouse and C. elegans orthologues, and also with the single D. melanogaster orthologue, lethal giant discs (Lgd) (Albert \& Lemonde, 2004; BaselVanagaite, et al., 2006). Structurally, full length CC2D1A protein and its orthologues consist of a helix-loop-helix (HLH) domain, a calcium-dependent C2 phospholipid binding domain (protein kinase C conserved region 2), a proline rich domain (Williamson, 1994), coiled coil motifs (Burkhard, et al., 2001) and four Drosophila melanogaster-14 (DM-14) domains of unknown function (Basel-Vanagaite, et al., 2003; Basel-Vanagaite, et al., 2006; Ou, et al., 2003) [Figure 1]. 


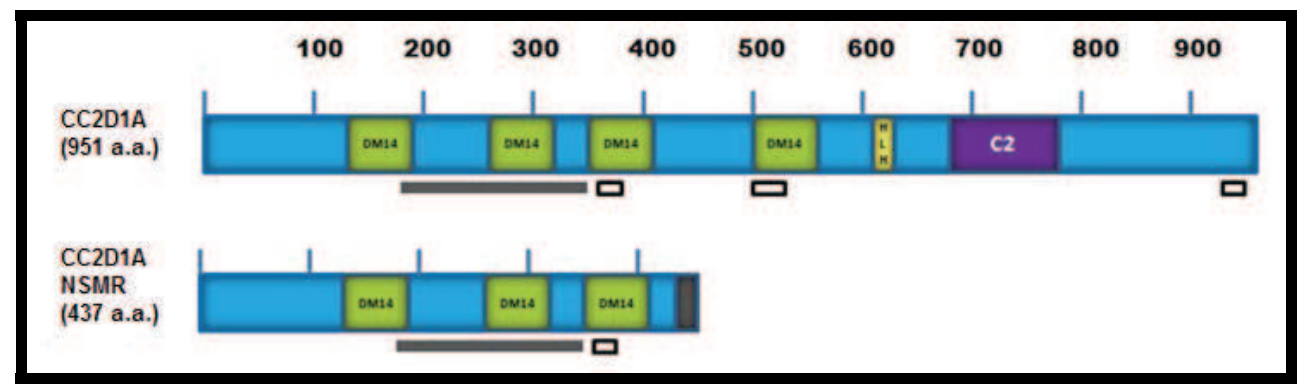

Fig. 1. Schematic of human CC2D1A protein.

Both full length and the NSMR truncation are shown, with C2 (purple), HLH (yellow), DM14 domains (green), coiled coil (open boxes) and proline rich (shaded box) regions indicated. The black box represents the sequence of 30 nonsense amino acids in the NSMR protein.

Long and short isoforms have been identified, with the short form lacking the first two DM14 domains. Both are functional, however, in humans, the long isoform predominates, while in rodents the short isoform appears to be the most common (Rogaeva \& Albert, 2007).

Our lab has identified widespread expression of CC2D1A in rodent brains by Northern blot analysis and in situ hybridization, with mRNA levels being highest in the cortex, hippocampus, raphe nuclei and substantia nigra (Ou, et al., 2003). Furthermore, CC2D1A mRNA expression has been observed in the murine brain from E12 to adulthood (BaselVanagaite, et al., 2006). Together, these findings allude to potential roles of CC2D1A throughout development and maturity in the rodent brain. Consistent with this distribution in the rodent, our lab has also confirmed similar tissue localization patterns in the human, again with Northern blot analysis indicating CC2D1A mRNA presence in the cortex, amygdala, hippocampus, thalamus (Rogaeva \& Albert, 2007). The extensive distribution of the protein spatially and its involvement in NSMR is suggestive of widespread activity both developmentally and in adult humans also.

Recent evidence suggests that CC2D1A, in addition to its relationship with NSMR, has an array of functions in animal models, with specific domains potentially accounting for these functions, although these are still relatively uncharacterized. They include the contribution of CC2D1A to regulating transcription, as well as Notch, Akt and NF-kB signaling and will be discussed in detail below (Figure 2). The dual transcription and signalling roles of CC2D1A imply its presence in both the nucleus and the cytoplasm, as we have shown in several human and rodent cell lines by biochemical fractionation (Rogaeva \& Albert, 2007), and in neurons by immunofluorescence (Ou, et al., 2003). However the extent of nuclear localization appears to be cell type dependent as a recent report found predominantly cytoplasmic localization of CC2D1A in HEK293 cells (Zhao, et al., 2010). Nonetheless, these data agree with the proposed cytoplasmic and nuclear regulatory roles and suggest regulation of its nuclear export (Rogaeva \& Albert, 2007). As well as transcriptional regulatory function, each of the signaling pathways mentioned has been implicated in regulating developmental processes, thus it is proposed that at least some of these pathways 
under the control of CC2D1A are disrupted when CC2D1A is compromised, affecting normative neuronal development. It is likely that a consequence of dysregulation of one or more of these systems may be the induction of developmental abnormalities that lead to MR.

\section{CC2D1A-mediated regulation of gene expression}

Initial identification of CC2D1A function using a screen for NF-kB activators suggested a limited role as an NF-kB signalling activation compared to other activators (Matsuda, et al., 2003). Subsequently, a yeast one-hybrid screen done in our lab identified the protein as a transcriptional repressor of the serotonin 1A (5-HT1A) receptor gene (Ou, et al., 2000; Ou, et al., 2003; Rogaeva \& Albert, 2007). The 5-HT1A receptor has been identified as an inhibitory G-protein coupled receptor, coupling specifically to Gi/Go proteins, resulting in decreased adenylyl cyclase activity, activation of potassium channels, and inhibition of calcium channels (Barnes \& Sharp, 1999; Lanfumey \& Hamon, 2004). The 5-HT1A receptor is expressed as both a somatodendritic autoreceptor on serotonin neurons in the raphe nuclei, and as heteroreceptors on serotonin targets including interneurons and pyramidal cells of the PFC and hippocampus and neurons of the hypothalamus, amygdala and septum (Aznar, et al., 2003; Varnas, et al., 2004). By hyperpolarizing the membrane potential, 5HT1A autoreceptor activation decreases both firing activity and 5-HT release, acting as a negative feedback circuit allowing serotonergic raphe neurons modulate their own activity in addition to the activity of neurons upon which they synapse. The 5-HT system, which originates in the raphe nuclei and projects broadly to the PFC, hippocampus, hypothalamus, amygdala and septum (Barnes \& Sharp, 1999), has been implicated in diverse functions, ranging from affect, pain, mood, stress response, sleep, aggression to appetite (Pucadyil, et al., 2005; Zhuang, et al., 1999). The preponderance of evidence regarding the developmental requirement of the 5-HT1A receptor has focused on its relationship to anxiety and depression. Initially, 5-HT1A receptor knockout studies identified increased anxiety- and decreased depression-like phenotypes in rodents (Heisler, et al., 1998; Parks, et al., 1998; Ramboz, et al., 1998), which could be rescued with early life postnatal overexpression (Gross, et al., 2002). Subsequent work indicated that suppression of 5-HT1A autoreceptors (but not heteroreceptors) throughout life increased anxiety-like responses, while developmental knockout of the heteroreceptors did increase depressive-like behaviours (Richardson-Jones, et al., 2010). The authors suggest increased developmental 5-HT neuron excitability as a plausible causative factor in the generation of anxiety phenotypes. These findings certainly point to the need for appropriate developmental regulation of 5-HT1A receptor expression in ensuring normative function in the adult. More pertinent to the discussion of NSMR is the finding that 5-HT1A receptor function has been linked to cognition. Atypical antipsychotics that are 5-HT1A receptor partial agonists improved cognitive function in the adult rodent (Schechter, et al., 2005; Sumiyoshi \& Meltzer, 2004). Conversely, knockout of the receptor results in impaired cognitive function (Sarnyai, et al., 2000), suggesting that impaired 5-HT1A activity during development may negatively impact later cognitive processes. Furthermore, the receptor is induced at later times during synaptic development to inhibit neuronal excitability of the prefrontal cortex (Beique, et al., 2004). Together these findings implicate the developmental importance of the 5-HT1A receptor in temporally and spatially appropriate sculpting of cortical circuitry and activity, which if disturbed may have repercussions leading to MR. 
Our lab demonstrated, via mutational analysis of the region upstream of the 5-HT1A transcription start site, the presence of a dual repressor element (DRE) which, when absent resulted in strongly enhanced 5-HT1A expression as evidenced by transcriptional reporter assays (Ou, et al., 2000). Subsequently, we used yeast one hybrid to identify CC2D1A as the regulatory protein responsible for 5-HT1A repression (Ou, et al., 2003). CC2D1A, also known as Freud-1 (five prime repressor under dual repression binding protein-1) was identified, and shown by electrophoretic mobility shift assay (EMSA) to bind the dual repressor element (DRE) (Ou, et al., 2003; Rogaeva \& Albert, 2007). The 31-base pair DRE is comprised of a $5^{\prime}$ - and a $3^{\prime}$ - repressor element and is highly conserved across rat, mouse, and human genes (Albert \& Lemonde, 2004). Upon binding to the DRE, CC2D1A repressed 5-HT1A receptor expression 10-fold in vitro, while mutation of the repressor element or increase in calcium levels abrogated these effects (Ou, et al., 2003; Rogaeva \& Albert, 2007), consistent with a role in regulation of gene expression. In order to elucidate the domains within CC2D1A required for binding to the DRE and repression, our lab is currently engaged in functional domain analysis, deleting key domains to explore their function. Preliminary work indicates that the NSMR-like mutant is incapable of binding the 5-HT1A DRE as seen with EMSA, nor is this mutant able to repress 5-HT1A expression in reporter assays (Millar, et al., 2011).

Similarly, our lab has shown, using EMSA and chromatin immunoprecipitation that CC2D1A binds a region homologous to the 5-HT1A-DRE in the dopamine D2 receptor promoter (D2-DRE), and demonstrated its repression of the D2 receptor using reporter assays (Rogaeva, et al., 2007). It is possible that CC2D1A-mediated dysregulation of 5-HT1A and D2 receptors may contribute to the developmental abnormalities seen in NSMR. However it is our contention that further genes will be identified as targets for modulation by CC2D1A and it is perhaps more likely that some of these other genes would be critical developmental regulators. Thus it is a current goal of our lab to identify other genes under the transcriptional control of CC2D1A and to examine the contribution of these genes to developmental regulation.

\section{CC2D1A and Notch signaling}

Notch signaling is a cell-cell signaling pathway found in and highly conserved across the animal kingdom. It has been shown to be involved in developmental regulation and in stem cell maintenance in an array of tissues, including the brain where it ensures normal neuronal structure and function (Lai, 2004). Of note, recent case studies have identified deletions within the 19p13.12-13.2 region (the same region containing CC2D1A), resulting in the loss of Notch3, as putatively causative factors in the development of syndromic MR (Engels, et al., 2007; Jensen, et al., 2009; Van der Aa, et al., 2010), thus this region may be particularly relevant to maintaining or directing the formation of developmentally accurate and functional neurocircuitry.

In mammals, the effectors in this signaling cascade are a family of four transmembrane receptors (NOTCH1-4) and associated ligands including Delta (Dll1, 3, 4) and Jagged (Jag1 and 2). The presence of multiple receptor and ligand types implies the ability to respond to a broad array of signals and in turn to differentially respond depending on the context. The Notch receptor is a large single-pass transmembrane receptor which upon ligand binding, is 
sequentially cleaved, triggering the Notch signaling cascade. The S2 cleavage event is catalyzed by the protease ADAM and cuts the extracellular segment (Brou, et al., 2000; Lieber, et al., 2002), permitting a subsequent cleavage event, which is mediated by a presenilin-dependent $\gamma$-secretase (De Strooper, et al., 1999; Struhl \& Greenwald, 1999). This S3 cleavage frees the Notch intracellular domain, which can then translocate to the nucleus where it interacts with the transcription factor CSL/Mastermind (Mam) to exert its effects on downstream target genes (among which is the HES family of developmentally relevant genes has been well studied).

Proper development demands an ordered process by which to establish and maintain correct pattern formation and differentiation. Both developmentally and in stem cell maintenance, Notch meets this demand via three distinct mechanisms: lateral inhibition, lineage decisions, and boundary formation/maintenance (as reviewed by Bray 2006)). With respect to lateral inhibition, Notch appears to magnify small differences in a population of cells, thereby determining cell fate (e.g., Notch regulates the number of cells that acquire neural potential). Lineage decisions refer to the finding that Notch determines whether progeny determined by lateral inhibition will differentiate into one cell type of another (e.g., neural or glial). This is accomplished by asymmetrical inheritance of Notch regulators which, in some cases or tissues, inhibits neural differentiation and in others promotes it. Boundary specification is critical in development and Notch signaling between two cell populations can define a boundary to organize/segregate the two groups. Dysregulation at any stage in this process could impair developmental processes necessary for normal neuronal structure and function.

Regulation of Notch activity is achieved in part by the spatial and temporal localization of Notch ligands, but in addition, its activity is tightly controlled by a number of other mechanisms, including endocytosis and ubiquitylation. Endocytosis was established as critical to Notch signaling by genetic studies in D. melanogaster (Parks, et al., 2000; Seugnet, et al., 1997). As Notch is a cell-surface receptor, its localization is at the plasma membrane, however, it is also found cytoplasmically, specifically within endocytic compartments. In D. melanogaster, Notch colocalizes with endosomal markers and when the endocytic cycle is perturbed, intracellular accumulation of Notch occurs (Jekely \& Rorth, 2003; Wilkin, et al., 2004). When sorting of ubiquitin-tagged membrane proteins (e.g., Endosomal Sorting Complex Required for Transport [ESCRT]) is disrupted, over-activation of the Notch pathway results. However, mutation of a number of endocytic components leads to increased Notch protein levels without affecting Notch function (Moberg, et al., 2005; Thompson, et al., 2005; Vaccari \& Bilder, 2005). In addition to endocytic control mechanisms, E3 ubiquitin ligases (e.g., Neuralized, Mindbomb) interact with Notch ligands and are required for Notch activation (Chitnis, 2006; Le Borgne, et al., 2005). The absence of the E3 ubiquitin ligases, Neuralized or Mindbomb, leads to abnormalities in Notch ligand trafficking resulting in ligand accumulation on the cell surface, although these accumulated ligands are inactive (Wang \& Struhl, 2005). These findings support a link between regulation of ligand activity by E3 ubiquitin ligases and endocytosis within the Notch pathway. Thus it is possible that disruption of these mechanisms could have relevance in development and by extension in NSMR.

Given the sequence identity and the domains shared between human CC2D1A and its D. melanogaster orthologue, lethal (2) giant discs (Lgd), it is of interest that the latter has been 
implicated in the regulation of Notch signalling. Lgd, a known tumour suppressor, modulates the Notch pathway by binding phospholipids on early endosomes and targeting Notch for trafficking to the degradative pathway (Childress, et al., 2006; Gallagher \& Knoblich, 2006; Jaekel \& Klein, 2006; Klein, 2003). In the endosomal pathway, ubiquitylated proteins are recognized by Hrs, a ubiquitin binding protein targeted to early endosomes. Hrs binds the ESCRTI complex which activates ESCRTII leading to ESCRTIII recruitment, to budding of vesicles into the endosome and to multivesicular body (MVB) formation (Raiborg \& Stenmark, 2009). Following fusion with lysosomes, the MBVs and their contents are degraded. In addition to involvement with MBVs, ESCRT proteins function in other fission events including the abscission stage in cytokinesis (Carlton, et al., 2008; Lindas, et al., 2008; Morita, et al., 2007; Samson, et al., 2008) and enveloped virus budding (Bieniasz, 2009). Mutations in Lgd result in abnormal accumulation of Notch and other transmembrane proteins (e.g., Delta and EGF receptor) within the early endosome (Gallagher \& Knoblich, 2006). This phenotype mimicked that seen with mutant ESCRT proteins which are essential for protein sorting to the degradative pathway (Moberg, et al., 2005; Thompson, et al., 2005; Vaccari \& Bilder, 2005). While it is undefined exactly why this protein trafficking deficit would lead to increased Notch activity, it is suggested that the most probable reason relates to the location of the final Notch cleavage event that leads to Notch activation (Gallagher \& Knoblich, 2006). Although it is unknown where this cleavage occurs, it has been shown that the cleavage enzyme presenilin localizes to and is active both at the plasma membrane and at endosomal membranes. Since the presenilin-mediated cleavage is required for Notch activation and lgd normally targets Notch to the endosome where it accumulates, it is postulated that Notch may be cleaved and activated by the protease within the endosome (Klein, 2003). This is consistent with evidence demonstrating that with lgd mutations, ectopic Notch signaling is ligand independent (Jaekel \& Klein, 2006). Together, these findings in D. melanogaster implicate a developmental role for Lgd in mediating endocytic control of Notch function.

Lgd bound to the monophosphorylated phosphatidyl inositides PI(3)P, PI(4)P and PI(5)P in vitro (Gallagher \& Knoblich, 2006), which is of interest given that the two former lipids have been shown to associate respectively with early endosomes and secretory vesicles (Czech, 2003). Deletion of the C-terminal region of Lgd, containing the phospholipid binding C2 domain, precluded binding to phospholipids, while a point mutation in the fourth DM14 domain generated a mutant phenotype reminiscent of that seen when Notch activity is dysregulated (Gallagher \& Knoblich, 2006), although it remains to be characterized whether mutating the fourth DM14 domain actually does disrupt Notch activity. With respect to developmental processes, normal pattern formation and differentiation in D. melanogaster wing development have been shown to depend on Notch activation (Klein, 2001). Throughout much of wing development, Notch activity is limited to the dorsoventral boundary, a function that is abrogated in lgd mutants (Klein, 2003). Furthermore, appropriate Notch activity is also a prerequisite for correct gene expression at this boundary (Klein, 2003). Disruption of lgd leads to ectopic activation of Notch signaling during wing development and sensory organ precursor cell selection (Klein, 2003). Further study identified the requirement of lgd in all imaginal disc cells to repress Notch activity (Jaekel \& Klein, 2006). It remains unclear exactly how or even whether Notch interacts directly with $\operatorname{lgd}$, however it appears that lgd exerts its effects between the early endosomal ubiquitin binding protein, Hrs, and the late endosomal component, Vps25 (Childress, et al., 2006; 
Gallagher \& Knoblich, 2006). Despite the lack of a comprehensive knowledge of this system, the literature does support a role for Notch in development which could be pertinent to neuronal development in humans.

Human CC2D1A has been shown to interact with the endocytic proteins, CHMP4B and CHMP4C (components of the ESCRT protein), potentially indicating a role for CC2D1A in endocytic trafficking pathways (Tsang, et al., 2006). Our preliminary work suggests that the phospholipid binding properties of CC2D1A mirror those of Lgd. Both proteins bind the monophosphorylated phosphatidyl inositides $\mathrm{PI}(3) \mathrm{P}, \mathrm{PI}(4) \mathrm{P}, \mathrm{PI}(5) \mathrm{P}$, while our work indicates that CC2D1A also appears to bind PA, and $\mathrm{PI}(3,4,5) \mathrm{P}_{3}$ (PIP3), perhaps suggesting additional functions in humans (Millar, et al., 2011). In CC2D1A, lack of the C2 domain or incorporation of a point mutation in the fourth DM14 domain (analogous to that in Lgd, discussed above) disrupts the lipid binding properties, again, echoing the findings in D. melanogaster. Consistent with these findings, the CC2D1A NSMR-like truncation mutant (which lacks the fourth DM14 domain, C2 domain and HLH domain) displayed loss of phospholipid binding capacity. Further study is ongoing in our lab to clarify the contribution of other domains within CC2D1A that may be required for phospholipid binding. It remains to be systematically examined whether the lipid binding abilities of CC2D1A are related to Notch activity as seen in D. melanogaster. If human CC2D1A regulates Notch as Lgd appears to, it is possible that mutations in CC2D1A result in perturbations in endosomal trafficking thereby altering Notch signaling, leading to the dysregulated neural development, which in turn may contribute to the pathogenesis of NSMR.

\section{CC2D1A and Akt function}

Akt is a serine threonine kinase, and three mammalian isoforms have been identified (Akt1, Akt2, Akt3), each possessing a pleckstrin homology ( $\mathrm{PH})$ domain, kinase domain and regulatory domain. Activation of Akt first requires stimulation by one of a number of upstream components, the most characterized of which is PI3K. When PI3K is recruited to the plasma membrane, it binds activated tyrosine kinases or G-protein coupled receptors. In response to growth factors, cytokines or receptors, activated PI3K phosphorylates the membrane phospholipid PIP2. The resultant PIP3 accumulates on the plasma membrane and Akt binds PIP3 and is thus recruited to the plasma membrane, which enables PDK1 phosphorylation of Akt at Thr308. Maximal Akt activation is achieved via additional (mTormediated) phosphorylation of Akt at Ser473. Akt is then directed to the nucleus where it directs a wide array of functions including cell survival, metabolism, proliferation, and differentiation via its interaction with multiple different substrates (Manning \& Cantley, 2007). Akt targets include NF-kB (Kane, et al., 1999; Ozes, et al., 1999; Romashkova \& Makarov, 1999), the proapoptotic protein BAD (del Peso et al, 1997; Luo et al., 2003), nitric oxide synthase (Dimmeler, et al., 1999; Fulton, et al., 1999; Michell, et al., 1999), glycogen synthase kinase 3 beta (Cross, et al., 1995).

Precise control of cortical development is required to generate structurally and functionally integrated neuronal networks and this requires correct orchestration of neuronal proliferation, migration, and differentiation (Chan, et al., 2002). The PI3K/Akt pathway has long been identified as a key regulator of cell survival and cell death, both developmentally 
and in the adult. Akt both directly and indirectly modulates apoptosis, one strategy by which projections are eliminated during development by directing the death of neurons that fail to make appropriate connections in the developing brain (Raff, et al., 1993). It does so by phosphorylating proteins or phosphorylating transcription factors that promote survival (Brunet, et al., 1999; Datta, et al., 1997; Qi, et al., 2006; Zhou, et al., 2001). Multiple sources suggest the involvement of the PI3K/Akt pathway as a critical developmental control in neurogenesis (Easton, et al., 2005; Kwon, et al., 2001; Peng, et al., 2004) and dendritogenesis (Jaworski, et al., 2005; Kumar, et al., 2005; Read \& Gorman, 2009). Akt has also been implicated in synaptogenesis (Akama \& McEwen, 2003) and synaptic transmission (Wang, et al., 2003). Others have found the pathway to be essential for elongation, guidance and branching of both axons and dendrites (Cosker, et al., 2008; Luikart, et al., 2008). These findings are consistent with the widespread distribution of Akt in the central nervous system. Implication of PI3K/Akt signaling in development is further supported by findings that disrupted PI3K via PTEN (an inhibitor of the PI3K/Akt pathway) antagonism leads to reduced neuronal proliferation (Groszer, et al., 2001) and the fact that Akt3 (the most common neuronal isoform) null mice exhibit decreased brain size and weight (Chin \& Toker, 2009; Tschopp, et al., 2005). Furthermore, Pten mutant mice have macrocephaly abnormal dendritic/axonal growth and synapse number and display social and behavioural deficits similar to that seen in autism (Chang, et al., 2007). Collectively, PI3K, Akt and mTor regulate Reelin's effect on growth and branching of hippocampal dendrites (Jossin \& Goffinet, 2007). In addition, altered Akt signaling has been implicated in common neurodevelopmental disorders, schizophrenia (Emamian, et al., 2004), and autism spectrum disorder (Levitt \& Campbell, 2009; Wiznitzer, 2004). Thus substantial evidence supports the developmental importance of Akt signaling as well as in cognitive function in the adult.

Given that Akt signalling is a developmentally significant pathway, it is of interest that it has been shown to be regulated by CC2D1A (Nakamura, et al., 2008). As mentioned, CC2D1A is localized to both the cytoplasm and the nucleus (Rogaeva \& Albert, 2007), thus it is reasonable to presume that its location within the cell determines its primary function, with nuclear localization being pertinent to transcriptional regulation and cytoplasmic localization relating to Akt-mediated cell survival. The importance of scaffold proteins in achieving signaling specificity has been highlighted, especially since in the Akt pathway, PDK1 is thought to be constitutively active and scaffolding provides a means of regulating PDK1 and by extension, Akt activity (Nakamura, et al., 2008). As a scaffold protein, CC2D1A promoted an EGFR-induced Akt/PDK1 interaction resulting in Akt activation and a subsequent increase in cell survival. In particular, overexpression of CC2D1A resulted in formation of the PDK1/Akt complex which upregulated Akt activity, while silencing of CC2D1A decreased Akt activity and increased apoptosis. EGF receptor stimulation was necessary to induce Akt activation and the receptor itself was incorporated in the CC2D1A/PDK1/Akt complex. CC2D1A knockdown did not affect the PI3K product, PIP3, but a PI3K inhibitor curbed the CC2D1A/Akt interaction, with no change in the CC2D1A/PDK1 interaction. CC2D1A increased the rate of PDK1-mediated phosphorylation and activation of Akt in the presence of PIP3. Our work has indicated that CC2D1A binds PIP3, thus it is possible that the increased rate of Akt activation may be dependent on the lipid binding properties of CC2D1A. Consistent with this, it was revealed that CC2D1A function required the presence of the fourth DM14 domain, as ablating this domain abrogated the interaction between CC2D1A and Akt/PDK1 (Nakamura, et al., 2008). This 
requirement for the fourth DM14 domain is significant given that a point mutant in this domain abrogated lipid binding (Millar, et al., 2011) and it is clinically relevant as the domain is absent in the CC2D1A mutation present in NSMR. These findings imply that CC2D1A lipid binding regulates multiple signaling pathways and suggest a possible developmental need for the fourth DM14 domain in Akt signaling, endocytosis and Notch signaling which may relate to NSMR pathogenesis. With respect to Akt signaling, further support for the involvement of Akt function in NSMR comes from the findings that Akt has been implicated in developmental disorders, CNS development, learning and memory, which it general, allude to a potential role for CC2D1A in brain development and cognitive function via its regulation of the cell survival promoting Akt signalling cascade.

\section{CC2D1A-mediated NF-kB activation}

Nuclear factor kappa enhancer binding protein (NF-kB) refers to a well characterized, evolutionarily conserved family of transcription factors which regulate multiple genes involved in cell survival, development, ischemia and immune response (Hayden \& Ghosh, 2008). Five mammalian subunits of NF-kB have been identified (RelA, RelB, cRel, p50, p52), with these subunits forming homo- or heterodimers to generate a functional transcription factor. The most prevalent subunits in neurons are p50 and p65 and it is subunit composition that determines whether the transcription factor activates or represses gene expression. Multiple ligands activate NF-KB in neurons, including but not limited to nerve growth factor (NGF) (Carter, et al., 1996; Maggirwar, et al., 1998), glutamate (Guerrini, et al., 1995), Fas (Cheema, et al., 1999), tumor necrosis factor-a (Barger, et al., 1995) intracellular calcium (O'Neill \& Kaltschmidt, 1997), neuropeptides (Frenkel, et al., 2002), as well as activation triggered by synaptic neurotransmission (Guerrini, et al., 1995). NF-kB exerts its effects via two distinct, but interacting pathways, termed the canonical and the noncanonical pathways. In the canonical NF-kB pathway, activation is mediated by a NEMO (IKKY)-dependent IKK which degrades IкB. NF-KB in its inactive state is sequestered in the cytoplasm by the inhibitor protein, ІкB. Ligand binding triggers signal transduction from TRAF to TAK1 which phosphorylates IKB kinase (IKK), activating it. Once activated, IKK phosphorylates IкB, targeting it for ubiquination and degradation. NF- $\mathrm{kB}$ is then freed and translocates to the nucleus where it exerts its effects on the expression of multiple genes. While in the non-canonical pathway activation is NEMO-independent and requires the processing of subunits p100 and p105 to mature and active forms.

NF-kB appears to be involved in brain development as it is active throughout development and some of the NF-KB ligands listed above are specific to the CNS. Disruption of NF-KB signaling has recently been noted in autosomal recessive MR (Philippe, et al., 2009), substantiating the developmental relevance of NF-kB functions in the brain. Furthermore, learning enhances the expression of genes containing NF- $\mathrm{KB}$ regulatory elements, supporting a role for NF-KB -mediated transcriptional regulation in cognitive function (Levenson, et al., 2004; O'Sullivan, et al., 2007). The presence of certain NF-KB subunits has been characterized as a determinant in regulating CNS development and in synaptic plasticity, learning and memory, specifically implicating the p50, RelA/p65 and cRel subunits (Ahn, et al., 2008; Kaltschmidt, et al., 2006; Meffert \& Baltimore, 2005; O'Riordan, et al., 2006). In addition, NF-kB subunit composition, particularly the p65:p50 heterodimer is activated by excitatory stimulation at hippocampal synapses (Kaltschmidt, et al., 1993; 
Meffert, et al., 2003; Suzuki, et al., 1997), a region key to learning and memory. Additionally, p65 null mice have defective hippocampal-dependent (spatial) learning (Meffert, et al., 2003), and display decreased dendrite spine formation and morphological abnormalities in the hippocampus (Boersma, et al., 2011). Knockout of the c-Rel subunit impaired contextual memory (Yeh, et al., 2002). Thus, there is evidence that NF-kB activity could underlie synaptic plasticity both during development and in the adult and it is possible that disruption of NF-kB-mediated processes during development and in the adult could contribute to the deficiencies evident in NSMR.

An initial report, screening for human genes that induced NF-kB signaling, identified $\mathrm{CC} 2 \mathrm{D} 1 \mathrm{~A}$ as an activator of NF-kB. Overexpression of CC2D1A, followed by reporter assays indicated that it could activate NF- $\mathrm{kB}$, albeit more weakly than other proteins that were characterized (Matsuda, et al., 2003). More recent work has corroborated this notion, as in vitro overexpression of CC2D1A resulted in a significant increase in NF-KB activation (Zhao, et al., 2010). Their work supports CC2D1A as a regulator in the canonical NF-kB pathway, as $\mathrm{CC} 2 \mathrm{D} 1 \mathrm{~A}-\mathrm{mediated}$ regulation of NF- $\mathrm{kB}$ activation required the presence of tumor necrosis factor receptor associated factor (TRAF2), the protein kinase TAK1, Ubc13 and the IкB kinase complex, all components of the canonical pathway. Subcellular localization of CC2D1A was determined to be primarily cytoplasmic, consistent with the location of inactive NF-kB. It remains unclear how or where within the NF-kB pathway that CC2D1A exerts its regulatory effects in this system, nor is it clear what signal triggers CC2D1A activity. However, the $\mathrm{C} 2$ domain is required to achieve NF-kB activation as deletion of this domain abrogated activation. Interestingly, a CC2D1A mutant resembling the truncation mutation in NSMR retained only $\sim 30 \%$ NF- $\mathrm{kB}$ activation levels relative to the full length CC2D1A. Thus given the developmental role of NF-KB and its relationship to cognitive function, CC2D1A-mediated regulation of this pathway may also be implicated in the dysregulated brain development which may be one contributing factor in the development of MR.

\section{CC2D1A and centrosomal function}

The mitotic cell cycle is a process within which cell division occurs, generating two daughter cells, each containing the full complement of the genome. A critical regulator of this is the centrosome, also referred to as the microtubule organizing centre (MTOC). The centrosome provides the bipolar microtubule spindle structure along which the chromosomes align and regulates sister chromatid separation. Thus defects in this apparatus could interfere with normal mitotic cell division and normal development. This is consistent with recent findings that centrosomal function has been implicated in human neural development and in particular, in microcephaly, which is accompanied by mental retardation. During the course of normal cortical development, the pool of progenitor cells expands, neurogenesis occurs, followed by neuronal migration and the formation of the cortical lamina. Interestingly, in mouse models with centrosomal abnormalities, there is a decrease in progenitor proliferation and neurogenesis occurs earlier, likely resulting in a decrease in the number of new neurons while migration is disrupted and the result is a dysplastic cortex. (Buchman, et al., 2010; Fish, et al., 2006; Lizarraga, et al., 2010; Manzini \& Walsh, 2011; Pulvers, et al., 2010). Aberrant cytoskeletal structure or function has been identified in 
cortical malformations and six of the seven genes implicated in microcephaly code for proteins related to the microtubule organizing centre in the centrosome (Manzini \& Walsh, 2011). Mutations in NDE1 (Bakircioglu, et al., 2011), CDK5RAP2 (Lizarraga, et al., 2010), STIL (Kumar, et al., 2009), WDR62 (Bilguvar, et al., 2010; Nicholas, et al., 2010; Yu, et al., 2010), ASPM, CENPJ, and CEP152 (Thornton \& Woods, 2009), all proteins with known or suspected involvement in centrosome function, have been identified in individuals with mental retardation (Manzini \& Walsh, 2011).

CC2D1A, together with cohesin, was shown to be required for normal centrosomal function (Nakamura, et al., 2009). CC2D1A localized to the centrosomes during interphase and mitosis and regulated centriole cohesion. siRNA targeted to CC2D1A resulted in multipolar spindles, misaligned chromosomes, cells arrested at the spindle checkpoint and resulted in fewer viable daughter cells. The C-terminal region of CC2D1A was shown to be required for centrosomal localization and the formation of bipolar spindles as full length, but not truncated CC2D1A rescued the multipolar spindle phenotype seen in cells depleted of CC2D1A. Centriole splitting has been suggested to arise from premature activation of separase (Thein, et al., 2007), an enzyme responsible for sister chromatid separation and centriole disengagement by cleaving the Scc1 subunit of cohesin (Thein, et al., 2007; Uhlmann, et al., 1999; Waizenegger, et al., 2000). Thus cells were treated with siRNA against separase and this was found to suppress the formation of multipolar spindles seen with CC2D1A depletion (Nakamura, et al., 2009). Furthermore, CC2D1A forms a complex with SMC1, a subunit of cohesin, and depletion of Scc1 resulted in multipolar spindles and arrest at spindle checkpoint, mirroring the effects of CC2D1A depletion. As CC2D1A siRNA decreased the level of Scc1 in the centrosomal fraction, it is suggested that normally, CC2D1A recruits cohesin to the spindle poles. Further work indicated that CC2D1A is phosphorylated during mitosis by cyclin B1-Cdk1 at Ser208, without which levels of Scc1CC2D1A complex are reduced, implying that this phosphorylation event may be regulating centrosome function (Nakamura, et al., 2010). Thus if CC2D1A regulates centrosome function, and aberrant centrosome activity is implicated in improper neural development and mental retardation, it is possible that this is relevant to the generation of NSMR in the CC2D1A truncation mutation.

CC2D1A may also affect centrosome function via its interaction with the ESCRT-III proteins CHMP4B and CHMP4C. ESCRT-III and VPS4 proteins are localized to the centrosomes, regulating both maintenance or proliferation and cell division at the midbodies during abscission (Carlton, et al., 2008; Lindas, et al., 2008; Morita, et al., 2007; Samson, et al., 2008). Cells lacking the ESCRT-III and VPS4 proteins displayed abnormalities in abscission, and unexpectedly, at earlier mitotic stages, with centrosome number, morphology and function being altered (Morita, et al., 2010). Given that human CC2D1A interacts with CHMP4B and CHMP4C, and that CC2D1A-targeted siRNA results in multipolar spindles, it is noteworthy that this same phenotype is evident in cells treated with siRNA to ESCRT-III/VPS4 proteins, specifically, CHMP1A, CHMP1B, CHMP2B, CHMP4B, CHMP4C, CHMP7, VPS4A, and VPS4B (Morita, et al., 2010). These cells additionally had greater numbers of centrosomes and spindles. Thus $\mathrm{CHMP} 4 \mathrm{~B}$ and $\mathrm{CHMP} 4 \mathrm{C}$ may mediate the effects of CC2D1A in regulating centrosome function, although it is unclear if this is the case or what specific mechanisms underlie this effect. 


\section{Conclusion}

In summary, it is possible that the truncation of CC2D1A seen in NSMR leads to the developmental dysregulation of: transcriptional repression of a multiple genes; Notch signalling; Akt activation; NF-kB-mediated regulation of transcription; and/or centrosome function (Figure 2). Jointly or independently, disruption of these functions may represent the molecular basis for the developmental defects in cognitive architecture and function detected in NSMR. As previously mentioned, a recent study has indicated that CC2D1A knockout is lethal upon birth in mice (Zhao, et al., 2011), suggesting the possibility that the domains remaining in the NSMR truncated protein do retain some function. While this knockout is relevant, it would be of substantial use to generate an animal model of the NSMR-like truncation mutant to dissect the involvement of these remaining domains and to identify whether this model could recapitulate some of the cognitive deficits in NSMR. Future studies to further characterize the molecular mechanisms underlying each of these functions are also necessary to clarify any contribution from each pathway in the pathogenesis of NSMR and to identify whether there is any interaction between these systems.

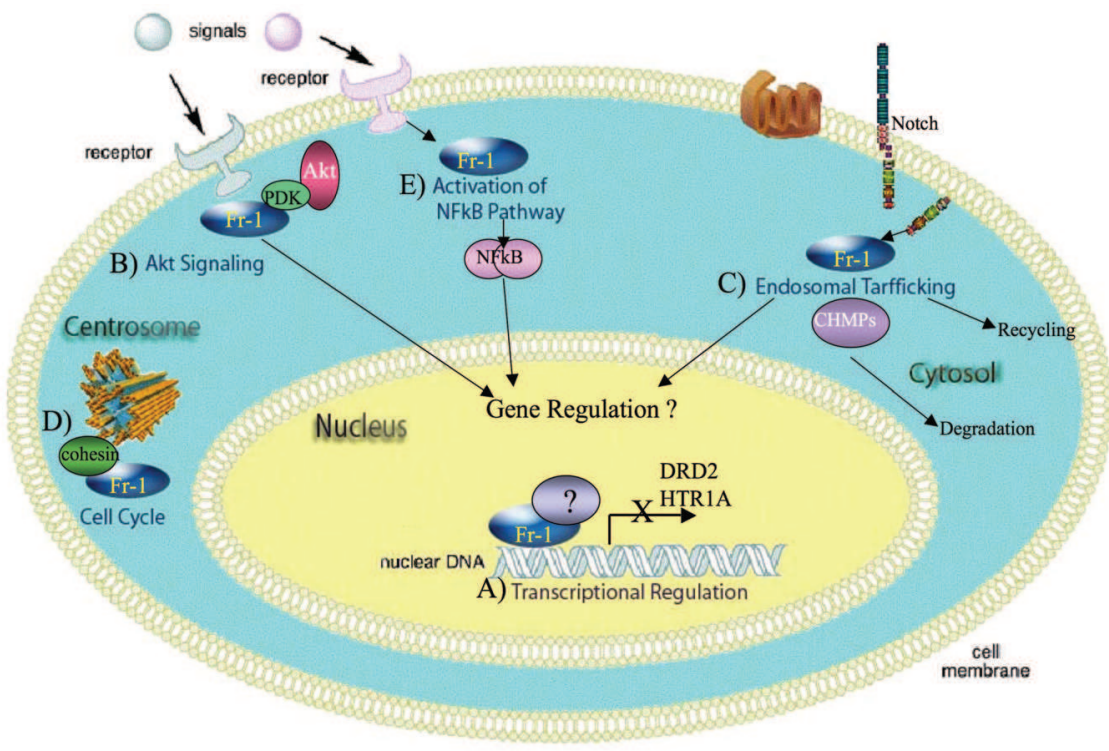

Fig. 2. Schematic of CC2D1A functions.

CC2D1A/Freud-1 (Fr-1) acts in the nucleus as a transcriptional repressor (A) and in the cytoplasm modulating Akt signaling (B), endosomal trafficking (C), cell cycle progression (D), and NF-kB activation (E).

Furthermore, functional domain analysis of CC2D1A will yield insight into which domains are required for each function and the degree to which each of the currently identified CC2D1A functions are important in the development of NSMR. As indicated above, it is evident that the C2 domain, as well as the fourth DM14 domain, are integral to some of the functions discussed here. This is of interest given that these two domains are absent in the NSMR truncation and intimates that the NSMR phenotype may be due to the disruption of 
cell survival and normative neuronal development that is perhaps attributable to the absence of these CC2D1A domains and the functions subsumed by each.

\section{References}

Ahn, H. J., C. M. Hernandez, J. M. Levenson, F. D. Lubin, H. C. Liou\&J. D. Sweatt. (2008). cRel, an NF-kappaB family transcription factor, is required for hippocampal longterm synaptic plasticity and memory formation. Learning $\mathcal{E}$ Memory, 15(7), 539-49.

Akama, K. T.\&B. S. McEwen. (2003). Estrogen stimulates postsynaptic density-95 rapid protein synthesis via the Akt/protein kinase B pathway. The Journal of Neuroscience, 23(6), 2333-9.

Albert, P. R.\&S. Lemonde. (2004). 5-HT1A receptors, gene repression, and depression: guilt by association. Neuroscientist, 10(6), 575-93.

American Psychiatric Association.\&American Psychiatric Association. Task Force on DSMIV. (2000). Diagnostic and statistical manual of mental disorders : DSM-IV-TR (4th ed.). Washington, DC: American Psychiatric Association.

Aznar, S., Z. Qian, R. Shah, B. Rahbek\&G. M. Knudsen. (2003). The 5-HT1A serotonin receptor is located on calbindin- and parvalbumin-containing neurons in the rat brain. Brain Research, 959(1), 58-67.

Bakircioglu, M., O. P. Carvalho, M. Khurshid, J. J. Cox, B. Tuysuz, T. Barak, S. Yilmaz, O. Caglayan, A. Dincer, A. K. Nicholas, O. Quarrell, K. Springell, G. Karbani, S. Malik, C. Gannon, E. Sheridan, M. Crosier, S. N. Lisgo, S. Lindsay, K. Bilguvar, F. Gergely, M. Gunel\&C. G. Woods. (2011). The essential role of centrosomal NDE1 in human cerebral cortex neurogenesis. The American Journal of Human Genetics, 88(5), 523-35.

Barger, S. W., D. Horster, K. Furukawa, Y. Goodman, J. Krieglstein\&M. P. Mattson. (1995). Tumor necrosis factors alpha and beta protect neurons against amyloid betapeptide toxicity: evidence for involvement of a kappa B-binding factor and attenuation of peroxide and $\mathrm{Ca} 2+$ accumulation. Proceedings of the National Academy of Sciences U S A, 92(20), 9328-32.

Barnes, N. M.\&T. Sharp. (1999). A review of central 5-HT receptors and their function. Neuropharmacology, 38(8), 1083-152.

Basel-Vanagaite, L., A. Alkelai, R. Straussberg, N. Magal, D. Inbar, M. Mahajna\&M. Shohat. (2003). Mapping of a new locus for autosomal recessive non-syndromic mental retardation in the chromosomal region 19p13.12-p13.2: further genetic heterogeneity. Journal of Medical Genetics, 40(10), 729-32.

Basel-Vanagaite, L., R. Attia, M. Yahav, R. J. Ferland, L. Anteki, C. A. Walsh, T. Olender, R. Straussberg, N. Magal, E. Taub, V. Drasinover, A. Alkelai, D. Bercovich, G. Rechavi, A. J. Simon\&M. Shohat. (2006). The CC2D1A, a member of a new gene family with $\mathrm{C} 2$ domains, is involved in autosomal recessive non-syndromic mental retardation. Journal of Medical Genetics, 43(3), 203-10.

Beique, J. C., B. Campbell, P. Perring, M. W. Hamblin, P. Walker, L. Mladenovic\&R. Andrade. (2004). Serotonergic regulation of membrane potential in developing rat prefrontal cortex: coordinated expression of 5-hydroxytryptamine (5-HT)1A, 5HT2A, and 5-HT7 receptors. The Journal of Neuroscience, 24(20), 4807-17.

Bieniasz, P. D. (2009). The cell biology of HIV-1 virion genesis. Cell HostEMicrobe, 5(6), 550-8. 
Bilguvar, K., A. K. Ozturk, A. Louvi, K. Y. Kwan, M. Choi, B. Tatli, D. Yalnizoglu, B. Tuysuz, A. O. Caglayan, S. Gokben, H. Kaymakcalan, T. Barak, M. Bakircioglu, K. Yasuno, W. Ho, S. Sanders, Y. Zhu, S. Yilmaz, A. Dincer, M. H. Johnson, R. A. Bronen, N. Kocer, H. Per, S. Mane, M. N. Pamir, C. Yalcinkaya, S. Kumandas, M. Topcu, M. Ozmen, N. Sestan, R. P. Lifton, M. W. State\&M. Gunel. (2010). Whole-exome sequencing identifies recessive WDR62 mutations in severe brain malformations. Nature, 467(7312), 207-10.

Birk, E., A. Har-Zahav, C. M. Manzini, M. Pasmanik-Chor, L. Kornreich, C. A. Walsh, K. Noben-Trauth, A. Albin, A. J. Simon, L. Colleaux, Y. Morad, L. Rainshtein, D. J. Tischfield, P. Wang, N. Magal, I. Maya, N. Shoshani, G. Rechavi, D. Gothelf, G. Maydan, M. Shohat\&L. Basel-Vanagaite. (2010). SOBP is mutated in syndromic and nonsyndromic intellectual disability and is highly expressed in the brain limbic system. The American Journal of Human Genetics, 87(5), 694-700.

Boersma, M. C., E. C. Dresselhaus, L. M. De Biase, A. B. Mihalas, D. E. Bergles\&M. K. Meffert. (2011). A requirement for nuclear factor-kappaB in developmental and plasticity-associated synaptogenesis. The Journal of Neuroscience, 31(14), 5414-25.

Bray, S. J. (2006). Notch signalling: a simple pathway becomes complex. Nature Reviews Molecular Cell Biology Biol, 7(9), 678-89.

Brou, C., F. Logeat, N. Gupta, C. Bessia, O. LeBail, J. R. Doedens, A. Cumano, P. Roux, R. A. Black\&A. Israel. (2000). A novel proteolytic cleavage involved in Notch signaling: the role of the disintegrin-metalloprotease TACE. Molecular Cell, 5(2), 207-16.

Brunet, A., A. Bonni, M. J. Zigmond, M. Z. Lin, P. Juo, L. S. Hu, M. J. Anderson, K. C. Arden, J. Blenis\&M. E. Greenberg. (1999). Akt promotes cell survival by phosphorylating and inhibiting a Forkhead transcription factor. Cell, 96(6), 857-68.

Buchman, J. J., H. C. Tseng, Y. Zhou, C. L. Frank, Z. Xie\&L. H. Tsai. (2010). Cdk5rap2 interacts with pericentrin to maintain the neural progenitor pool in the developing neocortex. Neuron, 66(3), 386-402.

Burkhard, P., J. Stetefeld\&S. V. Strelkov. (2001). Coiled coils: a highly versatile protein folding motif. Trends in Cell Biology, 11(2), 82-8.

Caliskan, M., J. X. Chong, L. Uricchio, R. Anderson, P. Chen, C. Sougnez, K. Garimella, S. B. Gabriel, M. A. dePristo, K. Shakir, D. Matern, S. Das, D. Waggoner, D. L. Nicolae\&C. Ober. (2011). Exome sequencing reveals a novel mutation for autosomal recessive non-syndromic mental retardation in the TECR gene on chromosome 19p13. Human Molecular Genetics, 20(7), 1285-9.

Carlton, J. G., M. Agromayor\&J. Martin-Serrano. (2008). Differential requirements for Alix and ESCRT-III in cytokinesis and HIV-1 release. Proceedings of the National Academy of Sciences U S A, 105(30), 10541-6.

Carter, B. D., C. Kaltschmidt, B. Kaltschmidt, N. Offenhauser, R. Bohm-Matthaei, P. A. Baeuerle\&Y. A. Barde. (1996). Selective activation of NF-kappa B by nerve growth factor through the neurotrophin receptor p75. Science, 272(5261), 542-5.

Chan, T. O., U. Rodeck, A. M. Chan, A. C. Kimmelman, S. E. Rittenhouse, G. Panayotou\&P. N. Tsichlis. (2002). Small GTPases and tyrosine kinases coregulate a molecular switch in the phosphoinositide 3-kinase regulatory subunit. Cancer Cell, 1(2), 18191. 
Chang, N., Y. H. El-Hayek, E. Gomez\&Q. Wan. (2007). Phosphatase PTEN in neuronal injury and brain disorders. Trends in Neurosciences, 30(11), 581-6.

Chechlacz, M.\&J. G. Gleeson. (2003). Is mental retardation a defect of synapse structure and function? Pediatric Neurology, 29(1), 11-7.

Cheema, Z. F., S. B. Wade, M. Sata, K. Walsh, F. Sohrabji\&R. C. Miranda. (1999). Fas/Apo [apoptosis]-1 and associated proteins in the differentiating cerebral cortex: induction of caspase-dependent cell death and activation of NF-kappaB. The Journal of Neuroscience, 19(5), 1754-70.

Childress, J. L., M. Acar, C. Tao\&G. Halder. (2006). Lethal giant discs, a novel C2-domain protein, restricts notch activation during endocytosis. Current Biology, 16(22), 222833.

Chin, Y. R.\&A. Toker. (2009). Function of Akt/PKB signaling to cell motility, invasion and the tumor stroma in cancer. Cell Signal, 21(4), 470-6.

Chitnis, A. (2006). Why is delta endocytosis required for effective activation of notch? Developmental Dynamics, 235(4), 886-94.

Cosker, K. E., S. Shadan, M. van Diepen, C. Morgan, M. Li, V. Allen-Baume, C. Hobbs, P. Doherty, S. Cockcroft\&B. J. Eickholt. (2008). Regulation of PI3K signalling by the phosphatidylinositol transfer protein PITPalpha during axonal extension in hippocampal neurons. Journal of Cell Science, 121(Pt 6), 796-803.

Cross, D. A., D. R. Alessi, P. Cohen, M. Andjelkovich\&B. A. Hemmings. (1995). Inhibition of glycogen synthase kinase-3 by insulin mediated by protein kinase B. Nature, 378(6559), 785-9.

Czech, M. P. (2003). Dynamics of phosphoinositides in membrane retrieval and insertion. Annual Review of Physiology, 65, 791-815.

Datta, S. R., H. Dudek, X. Tao, S. Masters, H. Fu, Y. Gotoh\&M. E. Greenberg. (1997). Akt phosphorylation of BAD couples survival signals to the cell-intrinsic death machinery. Cell, 91(2), 231-41.

De Strooper, B., W. Annaert, P. Cupers, P. Saftig, K. Craessaerts, J. S. Mumm, E. H. Schroeter, V. Schrijvers, M. S. Wolfe, W. J. Ray, A. Goate\&R. Kopan. (1999). A presenilin-1-dependent gamma-secretase-like protease mediates release of Notch intracellular domain. Nature, 398(6727), 518-22.

Dimmeler, S., I. Fleming, B. Fisslthaler, C. Hermann, R. Busse\&A. M. Zeiher. (1999). Activation of nitric oxide synthase in endothelial cells by Akt-dependent phosphorylation. Nature, 399(6736), 601-5.

Easton, R. M., H. Cho, K. Roovers, D. W. Shineman, M. Mizrahi, M. S. Forman, V. M. Lee, M. Szabolcs, R. de Jong, T. Oltersdorf, T. Ludwig, A. Efstratiadis\&M. J. Birnbaum. (2005). Role for Akt3/protein kinase Bgamma in attainment of normal brain size. Molecular and Cellular Biology, 25(5), 1869-78.

Emamian, E. S., D. Hall, M. J. Birnbaum, M. Karayiorgou\&J. A. Gogos. (2004). Convergent evidence for impaired AKT1-GSK3beta signaling in schizophrenia. Nature Genetics, 36(2), 131-7.

Engels, H., A. Brockschmidt, A. Hoischen, C. Landwehr, K. Bosse, C. Walldorf, G. Toedt, B. Radlwimmer, P. Propping, P. Lichter\&R. G. Weber. (2007). DNA microarray analysis identifies candidate regions and genes in unexplained mental retardation. Neurology, 68(10), 743-50. 
Fish, J. L., Y. Kosodo, W. Enard, S. Paabo\&W. B. Huttner. (2006). Aspm specifically maintains symmetric proliferative divisions of neuroepithelial cells. Proceedings of the National Academy of Sciences U S A, 103(27), 10438-43.

Frenkel, L., R. Freudenthal, A. Romano, V. E. Nahmod, H. Maldonado\&A. Delorenzi. (2002). Angiotensin II and the transcription factor Rel/NF-kappaB link environmental water shortage with memory improvement. Neuroscience, 115(4), 1079-87.

Fulton, D., J. P. Gratton, T. J. McCabe, J. Fontana, Y. Fujio, K. Walsh, T. F. Franke, A. Papapetropoulos\&W. C. Sessa. (1999). Regulation of endothelium-derived nitric oxide production by the protein kinase Akt. Nature, 399(6736), 597-601.

Gallagher, C. M.\&J. A. Knoblich. (2006). The conserved c2 domain protein lethal (2) giant discs regulates protein trafficking in Drosophila. Developmental Cell, 11(5), 641-53.

Garshasbi, M., V. Hadavi, H. Habibi, K. Kahrizi, R. Kariminejad, F. Behjati, A. Tzschach, H. Najmabadi, H. H. Ropers\&A. W. Kuss. (2008). A defect in the TUSC3 gene is associated with autosomal recessive mental retardation. The American Journal of Human Genetics, 82(5), 1158-64.

Gross, C., X. Zhuang, K. Stark, S. Ramboz, R. Oosting, L. Kirby, L. Santarelli, S. Beck\&R. Hen. (2002). Serotonin1A receptor acts during development to establish normal anxiety-like behaviour in the adult. Nature, 416(6879), 396-400.

Groszer, M., R. Erickson, D. D. Scripture-Adams, R. Lesche, A. Trumpp, J. A. Zack, H. I. Kornblum, X. Liu\&H. Wu. (2001). Negative regulation of neural stem/progenitor cell proliferation by the Pten tumor suppressor gene in vivo. Science, 294(5549), 2186-9.

Guerrini, L., F. Blasi\&S. Denis-Donini. (1995). Synaptic activation of NF-kappa B by glutamate in cerebellar granule neurons in vitro. Proceedings of the National Academy of Sciences U S A, 92(20), 9077-81.

Hayden, M. S.\&S. Ghosh. (2008). Shared principles in NF-kappaB signaling. Cell, 132(3), 34462.

Heisler, L. K., H. M. Chu, T. J. Brennan, J. A. Danao, P. Bajwa, L. H. Parsons\&L. H. Tecott. (1998). Elevated anxiety and antidepressant-like responses in serotonin 5-HT1A receptor mutant mice. Proceedings of the National Academy of Sciences U S A, 95(25), 15049-54.

Higgins, J. J., J. Pucilowska, R. Q. Lombardi\&J. P. Rooney. (2004). A mutation in a novel ATP-dependent Lon protease gene in a kindred with mild mental retardation. Neurology, 63(10), 1927-31.

Jaekel, R.\&T. Klein. (2006). The Drosophila Notch inhibitor and tumor suppressor gene lethal (2) giant discs encodes a conserved regulator of endosomal trafficking. Developmental Cell, 11(5), 655-69.

Jaworski, J., S. Spangler, D. P. Seeburg, C. C. Hoogenraad\&M. Sheng. (2005). Control of dendritic arborization by the phosphoinositide-3'-kinase-Akt-mammalian target of rapamycin pathway. The Journal of Neuroscience, 25(49), 11300-12.

Jekely, G.\&P. Rorth. (2003). Hrs mediates downregulation of multiple signalling receptors in Drosophila. EMBO Rep, 4(12), 1163-8.

Jensen, D. R., D. M. Martin, S. Gebarski, T. Sahoo, E. K. Brundage, A. C. Chinault, E. A. Otto, M. Chaki, F. Hildebrandt, S. W. Cheung\&M. M. Lesperance. (2009). A novel 
chromosome 19p13.12 deletion in a child with multiple congenital anomalies. The American Journal of Medical Genetics A, 149A(3), 396-402.

Jossin, Y.\&A. M. Goffinet. (2007). Reelin signals through phosphatidylinositol 3-kinase and Akt to control cortical development and through mTor to regulate dendritic growth. Molecular Cellular Biology, 27(20), 7113-24.

Kaltschmidt, B., D. Ndiaye, M. Korte, S. Pothion, L. Arbibe, M. Prullage, J. Pfeiffer, A. Lindecke, V. Staiger, A. Israel, C. Kaltschmidt\&S. Memet. (2006). NF-kappaB regulates spatial memory formation and synaptic plasticity through protein kinase A/CREB signaling. Molecular and Cellular Biology, 26(8), 2936-46.

Kaltschmidt, C., B. Kaltschmidt\&P. A. Baeuerle. (1993). Brain synapses contain inducible forms of the transcription factor NF-kappa B. Mechanisms of Development, 43(2-3), 135-47.

Kane, L. P., V. S. Shapiro, D. Stokoe\&A. Weiss. (1999). Induction of NF-kappaB by the Akt/PKB kinase. Current Biology, 9(11), 601-4.

Khan, M. A., M. A. Rafiq, A. Noor, N. Ali, G. Ali, J. B. Vincent\&M. Ansar. (2011). A novel deletion mutation in the TUSC3 gene in a consanguineous Pakistani family with autosomal recessive nonsyndromic intellectual disability. BMC Med Genet, 12, 56.

Klein, T. (2001). Wing disc development in the fly: the early stages. Curr Opin Genet Dev, 11(4), 470-5.

Klein, T. (2003). The tumour suppressor gene 1(2)giant discs is required to restrict the activity of Notch to the dorsoventral boundary during Drosophila wing development. Developmental Biology, 255(2), 313-33.

Kumar, A., S. C. Girimaji, M. R. Duvvari\&S. H. Blanton. (2009). Mutations in STIL, encoding a pericentriolar and centrosomal protein, cause primary microcephaly. The American Journal of Human Genetics, 84(2), 286-90.

Kumar, V., M. X. Zhang, M. W. Swank, J. Kunz\&G. Y. Wu. (2005). Regulation of dendritic morphogenesis by Ras-PI3K-Akt-mTOR and Ras-MAPK signaling pathways. The Journal of Neuroscience, 25(49), 11288-99.

Kwon, C. H., X. Zhu, J. Zhang, L. L. Knoop, R. Tharp, R. J. Smeyne, C. G. Eberhart, P. C. Burger\&S. J. Baker. (2001). Pten regulates neuronal soma size: a mouse model of Lhermitte-Duclos disease. Nature Genetics, 29(4), 404-11.

Lai, E. C. (2004). Notch signaling: control of cell communication and cell fate. Development, 131(5), 965-73.

Lanfumey, L.\&M. Hamon. (2004). 5-HT1 receptors. Curr Drug Targets CNS Neurol Disord, $3(1), 1-10$.

Le Borgne, R., A. Bardin\&F. Schweisguth. (2005). The roles of receptor and ligand endocytosis in regulating Notch signaling. Development, 132(8), 1751-62.

Leonard, H.\&X. Wen. (2002). The epidemiology of mental retardation: challenges and opportunities in the new millennium. Ment Retard Dev Disabil Res Rev, 8(3), 117-34.

Levenson, J. M., S. Choi, S. Y. Lee, Y. A. Cao, H. J. Ahn, K. C. Worley, M. Pizzi, H. C. Liou\&J. D. Sweatt. (2004). A bioinformatics analysis of memory consolidation reveals involvement of the transcription factor c-rel. The Journal of Neuroscience, 24(16), 3933-43. 
Levitt, P.\&D. B. Campbell. (2009). The genetic and neurobiologic compass points toward common signaling dysfunctions in autism spectrum disorders. J Clin Invest, 119(4), 747-54.

Lieber, T., S. Kidd\&M. W. Young. (2002). kuzbanian-mediated cleavage of Drosophila Notch. Genes Dev, 16(2), 209-21.

Lindas, A. C., E. A. Karlsson, M. T. Lindgren, T. J. Ettema\&R. Bernander. (2008). A unique cell division machinery in the Archaea. Proceedings of the National Academy of Sciences U S A, 105(48), 18942-6.

Lizarraga, S. B., S. P. Margossian, M. H. Harris, D. R. Campagna, A. P. Han, S. Blevins, R. Mudbhary, J. E. Barker, C. A. Walsh\&M. D. Fleming. (2010). Cdk5rap2 regulates centrosome function and chromosome segregation in neuronal progenitors. Development, 137(11), 1907-17.

Luikart, B. W., W. Zhang, G. A. Wayman, C. H. Kwon, G. L. Westbrook\&L. F. Parada. (2008). Neurotrophin-dependent dendritic filopodial motility: a convergence on PI3K signaling. The Journal of Neuroscience, 28(27), 7006-12.

Maggirwar, S. B., P. D. Sarmiere, S. Dewhurst\&R. S. Freeman. (1998). Nerve growth factordependent activation of NF-kappaB contributes to survival of sympathetic neurons. The Journal of Neuroscience, 18(24), 10356-65.

Manning, B. D.\&L. C. Cantley. (2007). AKT/PKB signaling: navigating downstream. Cell, 129(7), 1261-74.

Manzini, M. C.\&C. A. Walsh. (2011). What disorders of cortical development tell us about the cortex: one plus one does not always make two. Curr Opin Genet Dev, 21(3), 3339 .

Matsuda, A., Y. Suzuki, G. Honda, S. Muramatsu, O. Matsuzaki, Y. Nagano, T. Doi, K. Shimotohno, T. Harada, E. Nishida, H. Hayashi\&S. Sugano. (2003). Large-scale identification and characterization of human genes that activate NF-kappaB and MAPK signaling pathways. Oncogene, 22(21), 3307-18.

Meffert, M. K.\&D. Baltimore. (2005). Physiological functions for brain NF-kappaB. Trends in Neurosciences, 28(1), 37-43.

Meffert, M. K., J. M. Chang, B. J. Wiltgen, M. S. Fanselow\&D. Baltimore. (2003). NF-kappa B functions in synaptic signaling and behavior. Nat Neurosci, 6(10), 1072-8.

Michell, B. J., J. E. Griffiths, K. I. Mitchelhill, I. Rodriguez-Crespo, T. Tiganis, S. Bozinovski, P. R. de Montellano, B. E. Kemp\&R. B. Pearson. (1999). The Akt kinase signals directly to endothelial nitric oxide synthase. Current Biology, 9(15), 845-8.

Millar, A. M., T. S. Soulslova\&P. R. Albert. (2011). Mutational dissection of Freud-1/CC2D1A, a multi-functional protein implicated in mental retardation. Paper presented at the GRSNC, Montreal, QC Canada.

Mir, A., L. Kaufman, A. Noor, M. M. Motazacker, T. Jamil, M. Azam, K. Kahrizi, M. A. Rafiq, R. Weksberg, T. Nasr, F. Naeem, A. Tzschach, A. W. Kuss, G. E. Ishak, D. Doherty, H. H. Ropers, A. J. Barkovich, H. Najmabadi, M. Ayub\&J. B. Vincent. (2009). Identification of mutations in TRAPPC9, which encodes the NIK- and IKK-betabinding protein, in nonsyndromic autosomal-recessive mental retardation. The American Journal of Human Genetics, 85(6), 909-15. 
Moberg, K. H., S. Schelble, S. K. Burdick\&I. K. Hariharan. (2005). Mutations in erupted, the Drosophila ortholog of mammalian tumor susceptibility gene 101, elicit non-cellautonomous overgrowth. Developmental Cell, 9(5), 699-710.

Mochida, G. H., M. Mahajnah, A. D. Hill, L. Basel-Vanagaite, D. Gleason, R. S. Hill, A. Bodell, M. Crosier, R. Straussberg\&C. A. Walsh. (2009). A truncating mutation of TRAPPC9 is associated with autosomal-recessive intellectual disability and postnatal microcephaly. The American Journal of Human Genetics, 85(6), 897-902.

Molinari, F., F. Foulquier, P. S. Tarpey, W. Morelle, S. Boissel, J. Teague, S. Edkins, P. A. Futreal, M. R. Stratton, G. Turner, G. Matthijs, J. Gecz, A. Munnich\&L. Colleaux. (2008). Oligosaccharyltransferase-subunit mutations in nonsyndromic mental retardation. The American Journal of Human Genetics, 82(5), 1150-7.

Molinari, F., M. Rio, V. Meskenaite, F. Encha-Razavi, J. Auge, D. Bacq, S. Briault, M. Vekemans, A. Munnich, T. Attie-Bitach, P. Sonderegger\&L. Colleaux. (2002). Truncating neurotrypsin mutation in autosomal recessive nonsyndromic mental retardation. Science, 298(5599), 1779-81.

Morita, E., L. A. Colf, M. A. Karren, V. Sandrin, C. K. Rodesch\&W. I. Sundquist. (2010). Human ESCRT-III and VPS4 proteins are required for centrosome and spindle maintenance. Proceedings of the National Academy of Sciences U S A, 107(29), 12889-94.

Morita, E., V. Sandrin, H. Y. Chung, S. G. Morham, S. P. Gygi, C. K. Rodesch\&W. I. Sundquist. (2007). Human ESCRT and ALIX proteins interact with proteins of the midbody and function in cytokinesis. EMBO J, 26(19), 4215-27.

Motazacker, M. M., B. R. Rost, T. Hucho, M. Garshasbi, K. Kahrizi, R. Ullmann, S. S. Abedini, S. E. Nieh, S. H. Amini, C. Goswami, A. Tzschach, L. R. Jensen, D. Schmitz, H. H. Ropers, H. Najmabadi\&A. W. Kuss. (2007). A defect in the ionotropic glutamate receptor 6 gene (GRIK2) is associated with autosomal recessive mental retardation. The American Journal of Human Genetics, 81(4), 792-8.

Nakamura, A., H. Arai\&N. Fujita. (2009). Centrosomal Aki1 and cohesin function in separase-regulated centriole disengagement. The Journal Cell Biology, 187(5), 607-14.

Nakamura, A., M. Naito, H. Arai\&N. Fujita. (2010). Mitotic phosphorylation of Aki1 at Ser208 by cyclin B1-Cdk1 complex. Biochemical and Biophysical Research Communications, 393(4), 872-6.

Nakamura, A., M. Naito, T. Tsuruo\&N. Fujita. (2008). Freud-1/Aki1, a novel PDK1interacting protein, functions as a scaffold to activate the PDK1/Akt pathway in epidermal growth factor signaling. Molecular and Cellular Biology, 28(19), 5996-6009.

Nicholas, A. K., M. Khurshid, J. Desir, O. P. Carvalho, J. J. Cox, G. Thornton, R. Kausar, M. Ansar, W. Ahmad, A. Verloes, S. Passemard, J. P. Misson, S. Lindsay, F. Gergely, W. B. Dobyns, E. Roberts, M. Abramowicz\&C. G. Woods. (2010). WDR62 is associated with the spindle pole and is mutated in human microcephaly. Nature Genetics, 42(11), 1010-4.

Noor, A., C. Windpassinger, M. Patel, B. Stachowiak, A. Mikhailov, M. Azam, M. Irfan, Z. K. Siddiqui, F. Naeem, A. D. Paterson, M. Lutfullah, J. B. Vincent\&M. Ayub. (2008). CC2D2A, encoding a coiled-coil and C2 domain protein, causes autosomalrecessive mental retardation with retinitis pigmentosa. The American Journal of Human Genetics, 82(4), 1011-8. 
O'Neill, L. A.\&C. Kaltschmidt. (1997). NF-kappa B: a crucial transcription factor for glial and neuronal cell function. Trends in Neuroscience, 20(6), 252-8.

O'Riordan, K. J., I. C. Huang, M. Pizzi, P. Spano, F. Boroni, R. Egli, P. Desai, O. Fitch, L. Malone, H. J. Ahn, H. C. Liou, J. D. Sweatt\&J. M. Levenson. (2006). Regulation of nuclear factor kappaB in the hippocampus by group I metabotropic glutamate receptors. The Journal of Neuroscience, 26(18), 4870-9.

O'Sullivan, N. C., P. A. McGettigan, G. K. Sheridan, M. Pickering, L. Conboy, J. J. O'Connor, P. N. Moynagh, D. G. Higgins, C. M. Regan\&K. J. Murphy. (2007). Temporal change in gene expression in the rat dentate gyrus following passive avoidance learning. Journal of Neurochemistry, 101(4), 1085-98.

Ou, X. M., H. Jafar-Nejad, J. M. Storring, J. H. Meng, S. Lemonde\&P. R. Albert. (2000). Novel dual repressor elements for neuronal cell-specific transcription of the rat 5-HT1A receptor gene. The Journal of Biological Chemistry, 275(11), 8161-8.

Ou, X. M., S. Lemonde, H. Jafar-Nejad, C. D. Bown, A. Goto, A. Rogaeva\&P. R. Albert. (2003). Freud-1: A neuronal calcium-regulated repressor of the 5-HT1A receptor gene. The Journal of Neuroscience, 23(19), 7415-25.

Ozes, O. N., L. D. Mayo, J. A. Gustin, S. R. Pfeffer, L. M. Pfeffer\&D. B. Donner. (1999). NFkappaB activation by tumour necrosis factor requires the Akt serine-threonine kinase. Nature, 401(6748), 82-5.

Parks, A. L., K. M. Klueg, J. R. Stout\&M. A. Muskavitch. (2000). Ligand endocytosis drives receptor dissociation and activation in the Notch pathway. Development, 127(7), 1373-85.

Parks, C. L., P. S. Robinson, E. Sibille, T. Shenk\&M. Toth. (1998). Increased anxiety of mice lacking the serotonin1A receptor. Proceedings of the National Academy of Sciences U S A, 95(18), 10734-9.

Peng, Y., B. H. Jiang, P. H. Yang, Z. Cao, X. Shi, M. C. Lin, M. L. He\&H. F. Kung. (2004). Phosphatidylinositol 3-kinase signaling is involved in neurogenesis during Xenopus embryonic development. The Journal of Biological Chemistry, 279(27), 2850914.

Philippe, O., M. Rio, A. Carioux, J. M. Plaza, P. Guigue, F. Molinari, N. Boddaert, C. BoleFeysot, P. Nitschke, A. Smahi, A. Munnich\&L. Colleaux. (2009). Combination of linkage mapping and microarray-expression analysis identifies NF-kappaB signaling defect as a cause of autosomal-recessive mental retardation. The American Journal of Human Genetics, 85(6), 903-8.

Pucadyil, T. J., S. Shrivastava\&A. Chattopadhyay. (2005). Membrane cholesterol oxidation inhibits ligand binding function of hippocampal serotonin(1A) receptors. Biochemical and Biophysical Research Communications, 331(2), 422-7.

Pulvers, J. N., J. Bryk, J. L. Fish, M. Wilsch-Brauninger, Y. Arai, D. Schreier, R. Naumann, J. Helppi, B. Habermann, J. Vogt, R. Nitsch, A. Toth, W. Enard, S. Paabo\&W. B. Huttner. (2010). Mutations in mouse Aspm (abnormal spindle-like microcephaly associated) cause not only microcephaly but also major defects in the germline. Proceedings of the National Academy of Sciences U S A, 107(38), 16595-600.

Qi, X. J., G. M. Wildey\&P. H. Howe. (2006). Evidence that Ser87 of BimEL is phosphorylated by Akt and regulates BimEL apoptotic function. The Journal of Biological Chemistry, 281(2), 813-23. 
Raff, M. C., B. A. Barres, J. F. Burne, H. S. Coles, Y. Ishizaki\&M. D. Jacobson. (1993). Programmed cell death and the control of cell survival: lessons from the nervous system. Science, 262(5134), 695-700.

Raiborg, C.\&H. Stenmark. (2009). The ESCRT machinery in endosomal sorting of ubiquitylated membrane proteins. Nature, 458(7237), 445-52.

Ramboz, S., R. Oosting, D. A. Amara, H. F. Kung, P. Blier, M. Mendelsohn, J. J. Mann, D. Brunner\&R. Hen. (1998). Serotonin receptor 1A knockout: an animal model of anxiety-related disorder. Proceedings of the National Academy of Sciences U S A, 95(24), 14476-81.

Read, D. E.\&A. M. Gorman. (2009). Involvement of Akt in neurite outgrowth. Cellular and Molecular Life Sciences, 66(18), 2975-84.

Richardson-Jones, J. W., C. P. Craige, B. P. Guiard, A. Stephen, K. L. Metzger, H. F. Kung, A. M. Gardier, A. Dranovsky, D. J. David, S. G. Beck, R. Hen\&E. D. Leonardo. (2010). 5-HT1A autoreceptor levels determine vulnerability to stress and response to antidepressants. Neuron, 65(1), 40-52.

Rogaeva, A.\&P. R. Albert. (2007). The mental retardation gene CC2D1A/Freud-1 encodes a long isoform that binds conserved DNA elements to repress gene transcription. Eur The Journal of Neuroscience, 26(4), 965-74.

Rogaeva, A., X. M. Ou, H. Jafar-Nejad, S. Lemonde\&P. R. Albert. (2007). Differential repression by freud-1/CC2D1A at a polymorphic site in the dopamine-D2 receptor gene. TheJournal of Biological Chemistry, 282(29), 20897-905.

Romashkova, J. A.\&S. S. Makarov. (1999). NF-kappaB is a target of AKT in anti-apoptotic PDGF signalling. Nature, 401(6748), 86-90.

Samson, R. Y., T. Obita, S. M. Freund, R. L. Williams\&S. D. Bell. (2008). A role for the ESCRT system in cell division in archaea. Science, 322(5908), 1710-3.

Sarnyai, Z., E. L. Sibille, C. Pavlides, R. J. Fenster, B. S. McEwen\&M. Toth. (2000). Impaired hippocampal-dependent learning and functional abnormalities in the hippocampus in mice lacking serotonin(1A) receptors. Proceedings of the National Academy of Sciences U S A, 97(26), 14731-6.

Schechter, L. E., D. L. Smith, S. Rosenzweig-Lipson, S. J. Sukoff, L. A. Dawson, K. Marquis, D. Jones, M. Piesla, T. Andree, S. Nawoschik, J. A. Harder, M. D. Womack, J. Buccafusco, A. V. Terry, B. Hoebel, P. Rada, M. Kelly, M. Abou-Gharbia, J. E. Barrett\&W. Childers. (2005). Lecozotan (SRA-333): a selective serotonin 1A receptor antagonist that enhances the stimulated release of glutamate and acetylcholine in the hippocampus and possesses cognitive-enhancing properties. Journal of Pharmacology and Experimantal Therapeutics, 314(3), 1274-89.

Seugnet, L., P. Simpson\&M. Haenlin. (1997). Requirement for dynamin during Notch signaling in Drosophila neurogenesis. Developmental Biology, 192(2), 585-98.

Struhl, G.\&I. Greenwald. (1999). Presenilin is required for activity and nuclear access of Notch in Drosophila. Nature, 398(6727), 522-5.

Sumiyoshi, T.\&H. Y. Meltzer. (2004). Serotonin 1A receptors in memory function. The American Journal of Psychiatry, 161(8), 1505; author reply 1505-6.

Suzuki, T., S. Mitake, K. Okumura-Noji, J. P. Yang, T. Fujii\&T. Okamoto. (1997). Presence of NF-kappaB-like and IkappaB-like immunoreactivities in postsynaptic densities. Neuroreport, 8(13), 2931-5. 
Thein, K. H., J. Kleylein-Sohn, E. A. Nigg\&U. Gruneberg. (2007). Astrin is required for the maintenance of sister chromatid cohesion and centrosome integrity. The Journal Cell Biology, 178(3), 345-54.

Thompson, B. J., J. Mathieu, H. H. Sung, E. Loeser, P. Rorth\&S. M. Cohen. (2005). Tumor suppressor properties of the ESCRT-II complex component Vps25 in Drosophila. Developmental Cell, 9(5), 711-20.

Thornton, G. K.\&C. G. Woods. (2009). Primary microcephaly: do all roads lead to Rome? Trends in Genetics, 25(11), 501-10.

Tsang, H. T., J. W. Connell, S. E. Brown, A. Thompson, E. Reid\&C. M. Sanderson. (2006). A systematic analysis of human CHMP protein interactions: additional MIT domaincontaining proteins bind to multiple components of the human ESCRT III complex. Genomics, 88(3), 333-46.

Tschopp, O., Z. Z. Yang, D. Brodbeck, B. A. Dummler, M. Hemmings-Mieszczak, T. Watanabe, T. Michaelis, J. Frahm\&B. A. Hemmings. (2005). Essential role of protein kinase B gamma (PKB gamma/Akt3) in postnatal brain development but not in glucose homeostasis. Development, 132(13), 2943-54.

Uhlmann, F., F. Lottspeich\&K. Nasmyth. (1999). Sister-chromatid separation at anaphase onset is promoted by cleavage of the cohesin subunit Scc1. Nature, 400(6739), 37-42.

Vaccari, T.\&D. Bilder. (2005). The Drosophila tumor suppressor vps25 prevents nonautonomous overproliferation by regulating notch trafficking. Developmental Cell, 9(5), 687-98.

Van der Aa, N., G. Vandeweyer\&R. F. Kooy. (2010). A boy with mental retardation, obesity and hypertrichosis caused by a microdeletion of 19p13.12. Eur Journal of Medical Genetics, 53(5), 291-3.

Varnas, K., C. Halldin\&H. Hall. (2004). Autoradiographic distribution of serotonin transporters and receptor subtypes in human brain. Human Brain Mapping, 22(3), 246-60.

Waizenegger, I. C., S. Hauf, A. Meinke\&J. M. Peters. (2000). Two distinct pathways remove mammalian cohesin from chromosome arms in prophase and from centromeres in anaphase. Cell, 103(3), 399-410.

Wang, Q., L. Liu, L. Pei, W. Ju, G. Ahmadian, J. Lu, Y. Wang, F. Liu\&Y. T. Wang. (2003). Control of synaptic strength, a novel function of Akt. Neuron, 38(6), 915-28.

Wang, W.\&G. Struhl. (2005). Distinct roles for Mind bomb, Neuralized and Epsin in mediating DSL endocytosis and signaling in Drosophila. Development, 132(12), 2883-94.

Wilkin, M. B., A. M. Carbery, M. Fostier, H. Aslam, S. L. Mazaleyrat, J. Higgs, A. Myat, D. A. Evans, M. Cornell\&M. Baron. (2004). Regulation of notch endosomal sorting and signaling by Drosophila Nedd4 family proteins. Current Biology, 14(24), 2237-44.

Williamson, M. P. (1994). The structure and function of proline-rich regions in proteins. Biochem J, 297 ( Pt 2), 249-60.

Wiznitzer, M. (2004). Autism and tuberous sclerosis. Journal of Child Neurology, 19(9), 675-9.

Yeh, S. H., C. H. Lin, C. F. Lee\&P. W. Gean. (2002). A requirement of nuclear factor-kappaB activation in fear-potentiated startle. TheJournal of Biological Chemistry, 277(48), 46720-9. 
Yu, T. W., G. H. Mochida, D. J. Tischfield, S. K. Sgaier, L. Flores-Sarnat, C. M. Sergi, M. Topcu, M. T. McDonald, B. J. Barry, J. M. Felie, C. Sunu, W. B. Dobyns, R. D. Folkerth, A. J. Barkovich\&C. A. Walsh. (2010). Mutations in WDR62, encoding a centrosome-associated protein, cause microcephaly with simplified gyri and abnormal cortical architecture. Nature Genetics, 42(11), 1015-20.

Zhao, M., X. D. Li\&Z. Chen. (2010). CC2D1A, a DM14 and C2 domain protein, activates NFkappaB through the canonical pathway. The Journal of Biological Chemistry, 285(32), 24372-80.

Zhao, M., J. Raingo, Z. J. Chen\&E. T. Kavalali. (2011). Cc2d1a, a C2 domain containing protein linked to nonsyndromic mental retardation, controls functional maturation of central synapses. Journal of Neurophysiology, 105(4), 1506-15.

Zhou, B. P., Y. Liao, W. Xia, Y. Zou, B. Spohn\&M. C. Hung. (2001). HER-2/neu induces p53 ubiquitination via Akt-mediated MDM2 phosphorylation. Nature Cell Biology, 3(11), 973-82.

Zhuang, X., C. Gross, L. Santarelli, V. Compan, A. C. Trillat\&R. Hen. (1999). Altered emotional states in knockout mice lacking 5-HT1A or 5-HT1B receptors. Neuropsychopharmacology, 21(2 Suppl), 52S-60S. 


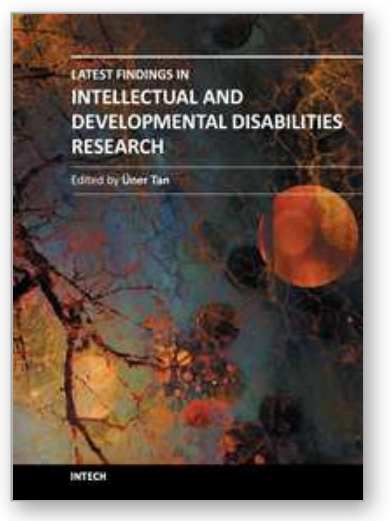

\author{
Latest Findings in Intellectual and Developmental Disabilities \\ Research \\ Edited by Prof. Uner Tan
}

ISBN 978-953-307-865-6

Hard cover, 404 pages

Publisher InTech

Published online 15, February, 2012

Published in print edition February, 2012

Intellectual and Developmental Disabilities presents reports on a wide range of areas in the field of neurological and intellectual disability, including habitual human quadrupedal locomotion with associated cognitive disabilities, Fragile $X$ syndrome, autism spectrum disorders, Down syndrome, and intellectual developmental disability among children in an African setting. Studies are presented from researchers around the world, looking at aspects as wide-ranging as the genetics behind the conditions to new and innovative therapeutic approaches.

\title{
How to reference
}

In order to correctly reference this scholarly work, feel free to copy and paste the following:

Anne M. Millar, Tatiana Souslova and Paul R. Albert (2012). The Freud-1/CC2D1A Family: Multifunctional Regulators Implicated in Mental Retardation, Latest Findings in Intellectual and Developmental Disabilities Research, Prof. Uner Tan (Ed.), ISBN: 978-953-307-865-6, InTech, Available from:

http://www.intechopen.com/books/latest-findings-in-intellectual-and-developmental-disabilities-research/thefreud-1-cc2d1a-family-multifunctional-regulators-implicated-in-mental-retardation

\section{INTECH}

open science | open minds

\section{InTech Europe}

University Campus STeP Ri

Slavka Krautzeka 83/A

51000 Rijeka, Croatia

Phone: +385 (51) 770447

Fax: +385 (51) 686166

www.intechopen.com

\section{InTech China}

Unit 405, Office Block, Hotel Equatorial Shanghai

No.65, Yan An Road (West), Shanghai, 200040, China

中国上海市延安西路65号上海国际贵都大饭店办公楼405单元

Phone: +86-21-62489820

Fax: +86-21-62489821 
(C) 2012 The Author(s). Licensee IntechOpen. This is an open access article distributed under the terms of the Creative Commons Attribution 3.0 License, which permits unrestricted use, distribution, and reproduction in any medium, provided the original work is properly cited. 